\title{
ADRENAL STEROIDS AND THE SECRETION OF DIGESTIVE ENZYMES*
}

\author{
By Burton L. Baker \\ Department of Anatomy, University of Michigan Medical School, Ann Arbor, Mich.
}

In his early (1855) description of the syndrome of adrenocortical deficiency in man, Thomas Addison ${ }^{1}$ drew attention to the severe gastrointestinal disturbance which may occur. More recent experimental studies further demonstrated that the adrenal cortex exerts an important supportive influence on the function of the alimentary tract. The absorption of fat, ${ }^{2}$ sodium chloride, ${ }^{3}$ and glucose ${ }^{4}$ is reduced by adrenalectomy. Maintenance of the animal on a salt regimen restores the absorptive rate for glucose $e^{4}$ to normal but fails to do so with respect to fat. ${ }^{2}$

Interference with secretory processes is indicated also by the reduction in weight of the gastrointestinal mucosa which follows adrenalectomy. ${ }^{5}$ The volume of gastric secretion is reduced in adrenocortical deficiency $6,7,8$ and treatment with desoxycorticosterone acetate and cortisone acetate has proved only partially effective in restoring this deficiency. ${ }^{9}$ Interference with the secretion of hydrochloric acid occurs also. The reduction in the amount of free acid in the stomachs of patients with Addison's disease is well known. In experimental animals, also, the secretion of acid is reduced by adrenalectomy. ${ }^{6,7}$ The volume and acidity of gastric secretion and the reduced intestinal absorption of $\mathrm{fat}^{2}$ are restored to normal in the adrenalectomized animal by the administration of Upjohn's Cortin.

This presentation is concerned with the role of adrenocortical hormones in the regulation of the cytology of and the secretion of enzymes by various serous cells associated with the digestive tract. Tuerkischer and Wertheimer ${ }^{7}$ were the first to demonstrate that the capacity of rats to produce rennin and pepsin is impaired by adrenalectomy, a condition which was corrected by administration of Upjohn adrenocortical extract. More recently, Gray and his collaborators ${ }^{10}$ have demonstrated that an increased secretion of pepsin and excretion of uropepsin in man results from treatment with corticotropin and cortisone. Little is known concerning the relationship of the adrenal cortex to the activity of other zymogenic cells.

The following zymogenic cells will be discussed: the gastric chief cells, and the epithelial cells of the parotid and pancreatic acini. Our work and that of others indicates that the hormonal background which regulates these cells is much broader than that exerted by the adrenal cortex alone. We shall attempt to assess the role of adrenocortical hormones in so far as the presently available fragmentary evidence will permit.

Hypophysectomy induces significant cytological changes in all of the types of zymogenic cells listed above. Gastric chief cells become smaller and are depleted of their pepsinogen granules and cytoplasmic ribonucleic acid. ${ }^{11}$ Concurrently, there is a reduction in the capacity of these cells to secrete pepsin

- These investigations were supported (in part) by research grants from the National Institutes of Health, United States Public Health Service [A-131(C2)], Bethesda, Md.; the University of Michigan-Memorial Phoenix Project (No. 57), Ann Arbor, Mich.; and The Upjohn Company, Kalamazoo, Mich. 
during a six-hour period after pyloric ligation. This suppression is detectable three days after pituitary ablation, and is reduced by 80 per cent at seven days.

As has been demonstrated by others ${ }^{12,13,14}$ and confirmed by us $^{15}$ in the rat, hypophysectomy results in a marked loss in weight of the pancreas. Cytologically, the acini became smaller and the intracellular content of zymogenic granules is reduced. The parotid gland presents a similarly striking atrophy following pituitary ablation. ${ }^{15}$

In order to ascertain the hormonal pathway by which the pituitary gland affects the zymogenic cells, it was necessary to study the effect of excision of other endocrine glands which are under the control of the anterior hypophysis. If pituitary control is exerted entirely through the adrenal cortex, adrenalectomy should induce changes comparable with those which occur after hypophysectomy. Evidence concerning this point is available with respect to the gastric chief cells. Cytologically, adrenalectomy induces an atrophy which, generally, is not as severe as that elicited by hypophysectomy. At three days after adrenalectomy, the mean peptic activity per ml. of gastric juice is 86.2 hemoglobin proteolytic* units ( $\mathrm{PU}^{\mathrm{Hb}} \times 10^{-4}$ ) and the total activity of the sample is $731 \times 10^{-4}$ in animals maintained on saline. ${ }^{16}$ Three days after hypophysectomy, however, the comparable figures are $80.0 \mathrm{PU}^{\mathrm{Hh}} \times 10^{-4}$ and $325 \mathrm{PU}^{\mathrm{Hb}} \times 10^{-4}$, respectively. The difference in the total activity of the juice in the two experiments is accounted for by the much greater drop in the volume of gastric juice secreted after hypophysectomy as compared with that after adrenalectomy. Maintenance of adrenalectomized rats on water instead of saline does not alter significantly the effect of the operation. Gonadectomy is without effect on the cytology or secretory capacity of the chief cells. Thyroidectomy does not modify the cytology, or concentration of peptic activity in the gastric juice. It does reduce the volume of juice produced and, thereby, the total peptic activity. A combination of adrenalectomy, thyroidectomy, and gonadectomy in the same animal induces a cytological and secretory change in the chief cells which, at seven days after the operation, is comparable with the effects induced by hypophysectomy. ${ }^{16}$ Thus, it appears that pituitary control of the chief cells is exerted primarily through the adrenal cortex with the thyroid being also involved.

Studies concerned with the restoration of the atrophied zymogenic cells of hypophysectomized rats by replacement therapy also support the conclusion that adrenocortical hormones play an important role in their regulation. The daily administration of hydrocortisone $\dagger$ to hypophysectomized rats beginning on the day of operation partially prevents the atrophy of the gastric chief cells which would be expected to occur during the succeeding seven days. ${ }^{16}$ Similarly, the daily injection of cortisone acetate to hypophysectomized rats beginning 9 to 13 days after the operation restores to normal the concentration of peptic activity of the gastric juice but, because of a cont inued depression of the volume of juice produced, the total peptic activity remains at a subnormal level. ${ }^{16}$ Thus, it is apparent that the adrenal cortex is involved in an important

\footnotetext{
* Hemoglobin proteolytic units of peptic activity $=\mathrm{mEq}$. of tyrosine released from henuglobin by pepsin of the gastric juice during one minute of digest ion at $3.5 .5^{\circ} \mathrm{C}$

$\dagger$ We extend our appreciation to Doctor Elmer Alpert of Merck and Co., Inc., Rahway, N. J., for generous supplies of hydrocortisone and cortisone acetate.
} 
way in the depression of chief cell activity which ensues after hypophysectomy. Since ablation experiments indicate that the thyroid might be involved also, replacement experiments were carried out in which thyroxine was administered.

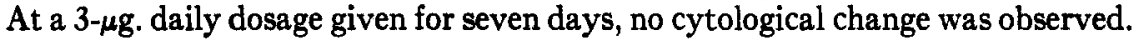
The capacity to secrete pepsin was not ascertained. The effect of higher doses given for longer periods of time remains to be investigated. Somatotropin modified the cytology but not the functional capacity of the cells. ${ }^{15}$ Thus, replacement studies confirm the evidence obtained from ablation experiments and indicate that adrenocortical steroids of the 11-oxygenated type are important in controlling the secretion of pepsin by chief cells.

Less information is available concerning the action of adrenocortical hormones on the pancreas and parotid gland of hypophysectomized animals. Administration of cortisone acetate $(0.5 \mathrm{mg}$. daily for 7 days, beginning 14 days after hypophysectomy) induces an increase in weight of the pancreas, although it is not restored to normal. This effect is of particular significance because the hormonal treatment causes a concurrent decrease in body weight. ${ }^{16}$ The weight of the parotid glands in these hypophysectomized rats was not increased by therapy with cortisone acetate.

In conclusion, it has been demonstrated that hypophysectomy causes severe atrophy of the zymogenic cells of three organs; i.e., stomach, pancreas, and parotid gland. Therapy with cortisone and/or hydrocortisone restores partially the structure and/or function of the gastric chief cells and acinar epithelium of the pancreas. This restoration has not been effected in the parotid. These findings are far from conclusive because varied doses and periods of therapy, as well as other adrenocortical steroids must be studied before the role of the adrenal cortex in the regulation of enzyme secretion will be entirely clear. As of the moment, this function appears to be an important one.

\section{References}

1. Addison, T. 1855. On the constitutional and local effects of disease of the supra-renal capsules. Highley. London, England.

2. Bavetra, L., L. Hallman, H. J. Deuel, JR. \& P. O. Greeley. 1941. The effect of adrenalectomy on fat absorption. Am. J. Physiol. 194: 619.

3. CLARK, W. G. 1939. Effect of adrenalectomy upon intestinal absorption of sodium chloride. Proc. Soc. Exptl. Biol. Med. 40: 468.

4. Althausen, T. L., E. M. ANDERson \& M. Stockholm. 1939. Effect of adrenalectomy and of $\mathrm{NaCl}$ on intestinal absorption of dextrose. Proc. Soc. Exptl. Biol. Med. 40: 342.

5. HaEger, K., D. JAcobsomn \& G. KaHLSON. 1953. Atrophy of the gastro-intestinal mucosa following hypophysectomy or adrenalectomy. Acta Physiol. Scand. Suppl. 111: 161 .

6. Haroutinan, L. M. \& H. L. Segal. 1952. The Shay rat as an assay animal for antiulcer factors: IV. The effect of adrenalectomy and nephrectomy. Gastroenterology. 21: 556.

7. TUERkischer, E. \& E. Werthemer. 1945. Adrenalectomy and gastric secretion. J. Endocrinology. 4: 143.

8. Madden, R. J. \& H. H. Ramsburg. 1951. Adrenalectomy in the Shay rat. Gastroenterology. 18: 128.

9. Madden, R. J. \& H. H. Ramsburg. 1951. Gastric secretion in the adrenalectomized rat. Endocrinology. 49: 82.

10. Gray, S. J., C. Ramsey, R. W. Reifenstein \& J. A. Benson, Jr. 1953. The significance of hormonal factors in the pathogenesis of peptic ulcer. Gastroenterology. 25: 156.

11. Baker, B. L. \& G. D. Abrams. 1954. Effect of hypophysectomy on the cytology of the 
fundic glands of the stomach and on the secretion of pepsin. Am. J. Physiol. 177: 409.

12. Koster, S. 1930. Experimentelle Lntersuchung der Hypophysenfunktion beim Hunde. Ptlüger's Arch. 224: 212.

13. GrIfFIrHs, M. 1941. The influence of anterior pituitary extracts on the insulin content of the pancreas of hypophysectomizer rats. J. Phy'siol. 100: 104.

14. Kinasi, B., I. Maciougali, M. A. Evans, F. E. Bryans \& R. E. Haist, 1953. Effects of anterior pituitary extracts and of growt hormone prejarations on the islets of Langerhans and the pancreas. Diabetes. 2: 112 .

15. BAKER, B. L. \& G. D. ABRAMS. Growth hormone (somatotropin) and the glands of the digestive system. In Proc. Intern. Symp. on The Hypophyseal Growth Hormone, Nature and Actions. Blakiston. In press.

10. Aвrams, G. D. \& B. L.. Bakrir. 1954. The cytology and secretory activity of gastric zymogenic cells aiter ablation of ductless glands. Gastroenterology. 27: 462 .

17. Glass, G. B. Jerzy, B. L. P'UGi \& S. Wolf. 1951. A new modification of the hemoglolin technic for the determination of pepsin in gastric juice arlapted for a wide range of values. Rev. Gastroenterology. 18: 670 . 